\title{
Effect of plant species on P cycle-related microorganisms associated with litter decomposition and $P$ soil availability: implications for agroforestry management
}

\author{
Eduardo Correa ${ }^{(1)}$, Lilia \\ Carvalhais ${ }^{(1)}$, Mirian Utida ${ }^{(2)}$, \\ Christiane Abreu Oliveira ${ }^{(2)}$, \\ Maria Rita Scotti ${ }^{(1)}$
}

\begin{abstract}
Cutting dry deciduous forest (preserved site) for wood supply in semi-arid Brazil has led to invasion of a pioneer shrub vegetation called "Carrasco" (disturbed site), which inhibits the sprouting of native species. A land restoration project was undertaken in a cleared Carrasco area where a mixed plantation of native species and Eucalyptus spp. (experimental site) was established to preserve the forest and ensure wood supply for the local population. We considered phosphorus as a limiting soil nutrient to plant growth, and we addressed the roles of litter decomposition and microbial activity on phosphorus release in the disturbed, preserved and experimental sites. The phosphorus released from leaf litter was affected by the vegetation type, which favored specific soil microbial populations during decomposition. The Carrasco vegetation predominantly favored arbuscular mycorrhizal fungi (AMF), as shown by root colonization in the litter bags; the Eucalyptus plants favored AMF and ectomycorrhizal fungi (EM), as well as phosphate solubilizing microorganisms (PSM), and the intercropping system favored AMF and PSM groups. In contrast, the preserved site favored the PSM population. High phosphatase activity was found in the preserved and experimental sites in contrast to the Carrasco soil. Principal component analysis showed that AMF root colonization and phosphatase activity were the main parameters influencing the increase in soil phosphorus. Based on the above results, rehabilitation appeared to be underway in the experimental site, since the samples were more similar to the preserved site than to the disturbed site. This effect was attributed to Eucalyptus camaldulensis that promote the establishment of all phosphorus cycle-related microorganisms (AMF, EM and PSF). E. camaldulensis associated with mycorrhizal fungi and PSM are recommended for inclusion in agroforestry systems.
\end{abstract}

Keywords: Agroforestry System, Arbuscular Mycorrhizal Fungi, Land Restoration, Litter Decomposition, Phosphate Solubilizing Microorganisms, Soil Phosphorus natural vegetation is cut down, a strong floristic shift occurs (Pagano et al. 2011), and the area is invaded by a dense community of pioneer species known as "Carrasco vegetation". Such invasive vegetation inhibits the sprouting of woody species and interferes with their succession. As a result, areas invaded by Carrasco are considered
(1) Department of Botany, Institute of Biological Science / Federal University of Minas Gerais . Avenida Antonio Carlos, 6627, Pampulha, Cep: 31.270-901 Belo Horizonte Minas Gerais (Brazil); (2) EMBRAPA- National Center of Maize and Sorgum Rod. MG. 424 Km 45 CEP: 35701970 Sete Lagoas- Minas Gerais (Brazil)

@ Maria Rita Scotti (mritascottimuzzi@gmail.com)

Received: Sep 29, 2014 - Accepted: Jun 22, 2015

Citation: Correa E, Carvalhais L, Utida M, Abreu Oliveira C, Scotti MR (2015). Effect of plant species on $\mathrm{P}$ cycle-related microorganisms associated with litter decomposition and $\mathrm{P}$ soil availability: implications for agroforestry management. iForest 9: 294-302. - doi: 10.3832/ifor1459-008 [online 2015-10-05]

Communicated by: Gianfranco Minotta disturbed sites (Rizzini 1997).

The strong demand for wood in this region has resulted in establishing a wood and energy provisions project for the local populations. As an alternative to re-vegetation with native species, an agroforestry system was proposed that uses a mixture of Eucalyptus spp. and native species (experimental site), thereby combining harmonious and concomitant wood production with land rehabilitation and preservation.

It is well known that forest litter fall is the major source of nutrient transfer to soil, particularly the mixed forests in agroforestry systems that enhance and maintain soil fertility and productivity (Nair \& Latt 1997). This effect has been attributed to improved soil organic matter (SOM) compared with that in monocultures (Lee \& Jose 2003).

Phosphorus is a common factor limiting the productivity in cultivated and degraded tropical soils (Appiah et al. 1997), as well as in semiarid ecosystems that require fertilization to ensure soil productivity. How- 
ever, this option could be expensive for farmers in developing countries. Therefore, land management practices, such as agroforestry systems, may enhance the biological activity in the soil and favor nutrient availability, which would reduce the need for the massive use of fertilizers.

According to the literature, a selected and effective composition of soil microorganisms and plants allows for a more efficient nutrient use or increases nutrient availability by providing solutions for present and future agricultural practices (Aggarwal et al. 2011), as occurs under natural conditions where the main source of nutrients is the soil organic matter. In terms of soil $P$ availability, the vegetation plays an important role in regulating $P$ distribution through litter decomposition and its cycling by microbial action (Singh et al. 1989).

Organic phosphorus is released through a mineralization process mediated by soil organisms and phosphatase secretion by plant roots and soil microorganisms. Decomposition of plant litter depends on the efficiency of the decomposer organisms and on the chemical composition of the leaf litter. Litter quality, in turn, is determined by carbon and nitrogen $(\mathrm{C}: \mathrm{N})$ or phosphorus (C:P) ratios, $\mathrm{N}$, lignin chemical composition, and the lignin: $\mathrm{N}$ ratio (Berg 2000). Litter from different species with different quality patterns may be differentially processed by specific groups of fungi and bacteria, and distinct microbial populations develop a feedback relationship with plant communities that vary across environments (Miki et al. 2010).

Plants can drive chemical and biological rhizospheric strategies involving plant phosphatases and/or elicit improvement in specific microbial groups, such as phosphate solubilizing microorganisms (PSM), to solubilize fixed phosphorus (Matias et al. 2009, Van der Heijden et al. 2008) and mycorrhizal fungi. Both endo- and ectomycor-

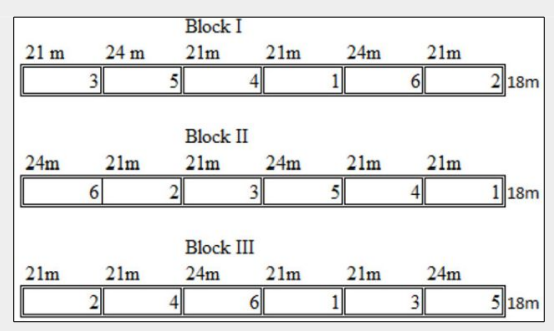

Fig. 1 - Experimental design at the study site with 6 treatments randomly distributed in each of the three blocks as follows: (1): monoculture of Plathymenia reticulata; (2): monoculture of $P$. reticulata inoculated with Rhizobium (R) and arbuscular mycorrhizal fungi (AMF)**; (3): monoculture of Eucalyptus camaldulensis; (4): monoculture of inoculated $E$. camaldulensis $(\mathrm{AMF})^{*} ;(5)$ : mixed plantation of $P$. reticulat $a$ and $E$. camaldulensis; and (6): mixed plantation of $P$. reticulata $\left({ }^{* *}\right)$ and $E$. camaldulensis (*). rhizal fungi increase the absorptive root surface and can reach the decomposing litter, which supplies the microbial population with additional nutrients (Herman et al. 2012) and where nutrients are released and distributed to plants via the mycorrhizal mycelium (Jalonen et al. 2013).

It is well known that agroforestry systems can improve soil organic matter inputs (Pagano et al. 2008), as well as the availability of soil $\mathrm{P}$ via litter decomposition (Partey et al. 2011) and phosphatases activity with intercropping age (Fuxu \& Ping 2004). Therefore, tree-based agroforestry systems, particularly those including Eucalyptus species, show an efficient return of soil nutrients (Mahmood et al. 2009, Pagano et al. 2008) that greatly contributes to the maintenance of soil fertility.

Considering that $\mathrm{P}$ is a limiting nutrient in semiarid soils, we hypothesized that different compositions of soil microbes and plants could increase $P$ availability and provide attractive agroforestry solutions in order to reduce phosphate fertilization. We investigated the influence of the agroforestry system composition (vegetation type) on litter decomposition and phosphorus release through $P$ cycle-related microbial activity such as mycorrhizal fungi and phosphate solubilizing microorganisms.

\section{Material and methods}

\section{Study area}

The study area is located in the Jaíba Irrigation District in the São Francisco river basin, northern Minas Gerais State, Brazil $\left(15^{\circ} 09^{\prime} 03^{\prime \prime} \mathrm{S}, 43^{\circ} 49^{\prime} 26^{\prime \prime} \mathrm{W}\right.$ ) in a semi-arid region. The natural vegetation is composed of woody Caatinga known as "dry forest", which is a deciduous forest composed of woody and shrub species (10-25 m of height) adapted to poor-nutrient soils (Rizzini 1997). When the woody Caatinga is cut, it is replaced by a dense, invasive community of pioneer species of low-load trees and shrub mesh, including spiny shrubs, known as "Carrasco vegetation" characterized by several dominant species: Piptadenia moniliformis (Benth) - Mimosaceae; Mimosa sp. - Mimosaceae; Croton glandulosus (L.) Muell. Arg. - Euphorbiaceae; Platymiscium praecox (Mart. Ex Benth) - Fabaceae; Acacia monacantha (Willd.) - Mimosaceae; Thiloa glaucocarpa (Spruce ex Eich.) - Combretaceae; and Tabebuia serratifolia (Vahl) Nich - Bignoniaceae (Del Rey 1991). The dominant native species of woody Caatinga are: Plathymenia reticulata, Tabebuia heptaphylla (Vell.) Toledo - Bignoniaceae; Myracrodruon urundeuva (Fr. Allem.) - Anacardiaceae; Machaerium stipitatum (Vog) Fabaceae, Enterolobium contortisiliquum (Vell.) Morong. - Mimosaceae; Anadenanthera peregrina (L.) - Mimosaceae; Aspidosperma multiflorum (A.DC.) - Apocynaceae; Schinopsis brasiliensis (Engl.) - Anacardiaceae; Terminalia argentea (Mart) - Combretaceae (Del Rey 1991). Plathymenia reticu- lata was chosen based on its dominance in the region and because it is strongly associated with the semi-arid climate (BSh) and is present in fragments of dry forest found in the eastern part of the São Francisco river basin (Arruda et al. 2013). Eucalyptus camaldulensis was selected to be intercropped due to its drought tolerance and adaptability to semiarid conditions.

\section{Field experimental design}

The experimental site was established ( 0.8 ha site s $^{-1}$ and was cleared of the "Carrasco" plants. Seedlings of selected plants were transplanted using a randomized block design (Fig. 1) with six treatments of 42 or 48 plants per plot, depending on whether the plot was located in a single or intercropped plantation. These treatments were randomly distributed in each of the three blocks at each site as shown in Fig. 1. The six treatments were allocated as follows: (i) four plots of $378 \mathrm{~m}^{2}(21 \times 18 \mathrm{~m}) \mathrm{cul}-$ tivated with 42 plants/treatment/block of a single species; and (ii) two plots of $432 \mathrm{~m}^{2}$ $(24 \times 18 \mathrm{~m})$ with 48 plants in lines cultivated with one of the three selected species with a spacing of $3 \times 3 \mathrm{~m}$. These 6 treatments (one per plot) were irrigated for approximately 10 months. The experimental site included the following treatments/block:

(i) T1 - monoculture of Plathymenia reticulata plus complete fertilization (CF);

(ii) $\mathrm{T} 2$ - monoculture of $P$. reticulata inoculated with Rhizobium (R) and arbuscular mycorrhizal fungi (AMF) species plus $80 \%$ fertilization (80 F);

(iii) $\mathrm{T} 3$ - monoculture of Eucalyptus camaldulensis plus $\mathrm{CF}$;

(iv) $\mathrm{T} 4$ - monoculture of inoculated $\mathrm{E}$. camaldulensis (AMF) plus $80 \mathrm{~F}$;

(v) $\mathrm{T}_{5}$ - mixed plantation of P. reticulata and E. camaldulensis plus CF; and

(vi) T6 - mixed plantation of P. reticulata and $\mathrm{E}$. camaldulensis and both species inoculated with $\mathrm{R}$ and/or AMF plus $80 \mathrm{~F}$.

Complete fertilization was performed according to Somasegaran \& Hoben (1985) and consisted of triple superphosphate (500 kg ha-1), $\mathrm{KCl}\left(382 \mathrm{Kg} \mathrm{ha}^{-1}\right), \mathrm{MgSO}_{4} \cdot 7 \mathrm{H}_{2} \mathrm{O}$ (50 kg ha-1), $\mathrm{ZnSO}_{4} \cdot 7 \mathrm{H}_{2} \mathrm{O}\left(46.8 \mathrm{~kg} \mathrm{ha}{ }^{-1}\right.$ ), $\mathrm{Mo}_{7} \mathrm{O}_{2} .4 \mathrm{H}_{2} \mathrm{O}\left(1.76 \mathrm{~kg} \mathrm{ha}^{-1}\right)$, and urea $(222 \mathrm{~kg}$ $\mathrm{ha}^{-1}$ ) at the beginning of plantation. Far from the experimental area, an undisturbed, $1000 \mathrm{~m}^{2}$ fragment in the Preserved site (7500 ha) was used as a control for the preserved site, and an area invaded by Carrasco vegetation $\left(1000 \mathrm{~m}^{2}\right)$ was used as a control for the disturbed site. The same experimental design (3 blocks and 3 plots/block) was established in each control area.

\section{Inoculants}

The rhizobia strain BHICB-PI 02 was selected based on a previous screen for its effectiveness at nitrogen fixation in relation to $P$. reticulata under greenhouse, nursery and field conditions (data not shown). The plants were cultivated in plastic soil 
pots $\left(700 \mathrm{~cm}^{3}\right)$ and inoculated with $1 \mathrm{ml}$ of rhizobia plant ${ }^{-1}\left(10^{7} \mathrm{cfu} \mathrm{ml}^{-1}\right.$ - Somasegaran \& Hoben 1985) under nursery conditions. The field transplantation occurred after 4 months. Arbuscular mycorrhizal fungi (AMF) inocula consisted of $1 \mathrm{ml} \mathrm{pot}^{-1}$ of a suspension composed of 150 spores $\mathrm{ml}^{-1}$ of an equal mixture of 3 species: Gigaspora margarita, Scutellospora heterogama and Glomus sp. from the ICB-UFMG collection. While Eucalyptus camaldulensis plants received only the AMF inocula, $P$. reticulata plants received a double inoculation of rhizobia and AMF.

\section{Soil samples and analysis}

Soil samples were collected at 12 and 24 month intervals (soil sampling auger with $20 \mathrm{~cm}$ of deep) for a total of 9 samples/ treatment/block/site ( 3 mixed samples $\times 6$ treatments $\times 3$ blocks) or 54 samples from each experimental site. A similar transect was made in the "Carrasco" area and in the Preserved site where 27 samples were collected per site $(3$ mixed samples $\times 3$ plots $\times$ 3 blocks). The chemical and physical properties of samples were analyzed according to the Brazilian National standard recommendations (EMBRAPA 1997).

\section{Litter sampling}

Recently fallen leaves of adult plants were collected and air dried to a constant weight at room temperature, and then cut and enclosed in $12 \times 13 \mathrm{~cm}$ nylon bags (12 g per bag) with a $1 \mathrm{~mm}$ mesh. Nine sub-samples of each litter type were retained for initial moisture and chemical analysis. The randomized field experimental design utilized 3 litter types ( $P$. reticulata, E. camaldulensis and mixed) distributed in 6 treatments and 3 blocks with 9 replicates/litter type/site/time deposited in the litter layer. The litter bags were collected after 4 (dry season) and 8 (rainy season) months of incubation, and the leaf litters were cleaned and weighed (fresh weight) before and after drying at $60{ }^{\circ} \mathrm{C}$ and $80{ }^{\circ} \mathrm{C}$, respectively, for $48 \mathrm{~h}$. Corrections for inorganic contaminants were made after determining ash content $\left(4 \mathrm{~h}\right.$ at $\left.500^{\circ} \mathrm{C}\right)$.

\section{Decomposition rates and chemical composition}

Weight loss data were estimated as follows (Wesemael 1993 - eqn. 1):

$$
R M=\frac{W_{0}-W_{t}}{W_{0}} \cdot 100
$$

where $W_{0}$ is the initial litter dry weight, and $W_{\mathrm{t}}$ is the dry weight of the remaining mass $(R M)$ of litter in the bag at the time of collection. The decay rate $\left(\mathrm{k}\right.$ year $\left.{ }^{-1}\right)$, which estimates the litter disappearance on a yearly basis and is proportional to actual decomposition rates, was calculated using the following negative exponential decay function (Olson 1963 - eqn. 2):

$$
W_{t}=W_{0}^{(e-k t)}
$$

Chemical analysis of the residue, including soluble components, hemicellulose, cellulose and lignin, was performed using the acid detergent fibre method (Goering \& Van Soest 1970). The analysis of nitrogen was performed using Nessler's reagent method (Oliveira 1986), and the analysis of phosphorus was performed using the Vanado-molybdate method described by Sarruge \& Haag (1974).

\section{Mycorrhizal root colonization in litter bags}

Fine roots were collected from inside the litter bags after 8 months of incubation, fixed in a FAA solution cleared and stained with Trypan Blue and then evaluated for AMF colonization according to McGonigle et al. (1990). The results were expressed as the percentage of colonized segments. Eucalyptus root samples were checked for natural ectomycorrhizal colonization and quantified by the line intercept method of McGonigle et al. (1990). The presence of a fungal mantle and the Hartig net were considered as evidence of ectomycorrhizal coIonization. Percent colonization data were transformed as arcsine $(x / 100) / 2$.

\section{Microbial biomass and carbon determination}

Soil samples from and around the mixed litter bags buried at each site were sieved through a $2 \mathrm{~mm}$ mesh screen and dried overnight at $105^{\circ} \mathrm{C}$ to determine the moisture content. They were then used to evaluate the biomass $\left(\mathrm{C}_{\text {mic }}\right)$ according to the fumigation method of Vance et al. (1987).

\section{Phosphate-solubilizing microorganisms} (PSMs) and acid phosphatase activity Soil samples from nine mixed litter bags per site ( $1 \mathrm{~g}$ of soil) were collected close to the litter bags in the rhizospheric zone and the number of PSMs were analyzed using the Pikovskaya's medium (5.0 $\mathrm{g} \mathrm{Ca}_{3} \mathrm{PO}_{4}$, $10.0 \mathrm{~g}$ Glicose, $0.5 \mathrm{~g}\left(\mathrm{NH}_{4}\right)_{2} \mathrm{SO}_{4}, 0.2 \mathrm{~g} \mathrm{NaCl}$, $0.1 \mathrm{~g} \mathrm{MgSO}_{4} .7 \mathrm{H}_{2} \mathrm{O}, 0.001 \mathrm{~g} \mathrm{MnSO}_{4}, 0.001 \mathrm{~g}$ $\mathrm{FeSO}_{4}$ - $15 \mathrm{~g}$ per L, pH: 6.0 - Pikovskaya 1948). PSM numbers were determined from the colony-forming units (CFU), and morphologically distinct colonies, both with and without halos, were purified by repeated sub-culturing, maintained on potato dextrose agar and incubated at room temperature. The data from the 9 samples collected near the mixed litter bags from each site were compared by Tukey's multiple-range test.

The dominant fungi morphotypes found near each litter bag were isolated and grown in modified Pikovskaya's medium (Lapeyrie et al. 1990), and phosphate solubilization activity was estimated according to Nguyen et al. (1992), considering the diameter of halo and colony growth (eqn. 3):

$$
E=\left(D_{h} \cdot 100\right) \cdot D_{c g}
$$

where $E$ is the solubilizing efficiency, $D_{\mathrm{h}}$ is the diameter of the halo, and $D_{\mathrm{cg}}$ is the diameter of colony growth. The data were grouped into low, intermediate, high and very high $\mathrm{P}$ solubilization efficiency classes based on this $E$ index (Sampaio 2002).

The DNA of the fungal isolates was obtained according to Lee \& Taylor (1990). The primers ITS (internal transcribed spacer) 1 (5'-TCC GTA GGT GAA CCT GCG G-3') and ITS 4 (5'-TCC TCC GCT TAT TGA TAT GC-3') were used to amplify an rDNA ITS region (White et al. 1990). The sequences obtained were then analyzed and compared to those deposited in the Gen Bank Nucleotide Database using the BLAST program.

Soil samples from 9 mixed litter bags from each site ( $1 \mathrm{~g}$ of soil) were put in a modified universal buffer (MUB) with $\mathrm{pH}$ 6.5, and the acid phosphatase activities in the soil samples were determined by the method described in Tabatabai (1982).

\section{Statistical analysis}

The data were subjected to one-way ANOVA using the statistical software package MINITAB $^{\circledast}$ version 13.2 (Minitab Inc., State College, PA, USA), and the means compared using the Tukey's test $(P \leq 0.05)$.

$\mathrm{AMF}$ and EMF root colonization (\%) data were transformed as arcsine $(x / 100) / 2$. The data were subjected to one-way ANOVA.

In relation to phosphate solubilizing fungi (PSF) sequences, a cluster analysis was performed by applying an unweighted pair group method with arithmetic averaging (UPGMA). All phylogenetic analyses were performed using the software package MEGA4 ${ }^{\circledast}$ (Biodesign Inst., Tempe, AZ, USA). PSF species identified via BLAST were clustered based on the Sørensen's index using the UPGMA algorithm in the MINITAB 13.2 to visualize the PSM community composition patterns from each site.

Principal component analysis (PCA) based on the covariance matrix was applied to analyze the relationships among the parameters related to phosphorus metabolism, such as soil organic matter (SOM), phosphorus concentration, acid phosphatase activity, PSM number, AMF root colonization index and AMF spore number (Pagano et al. 2011). The results were plotted by dispersion and loading plots using the software package MINITAB $^{\oplus}$ version 16 .

\section{Results}

\section{Soil analysis}

The sandy soil samples were poor in all nutrients (Tab. 1). Twenty-four months after transplantation, improvements in nutrient and soil organic matter (SOM) content, CEC and soil porosity were observed in all of the treatments at the experimental site. Phosphorus was especially limiting in the experimental area before transplantation, but after 24 months there was an increase in the $P$ levels of the soils from plots cultivated with eucalyptus (treatments $T_{3}, T_{4}, T_{5}$ and $T_{6}$ ) and inoculated with AMF. Similarly, $P$ was exceptionally high in the Carrasco soil. 
Tab. 1 - Soil characteristics of the treatments after 12 and/or 24 months. (T1): Plathymenia reticulata; (T2): P. reticulata plus rizobia and AMF; (3): E. camaldulensis; (4): E. camaldulensis plus AMF; (5): P. reticulata intercropped with E. camaldulensis; (T6): P. reticulata plus rizobia and AMF intercropped with E. camaldulensis plus AMF; (Exp): Experimental site before transplantation; (P): Preserved site; (C): Carrasco vegetation; (BS): Base saturation; (CEC): Cation exchange capacity. Different letters in the same row indicate significant differences among the means after the Tukey's test $(P \leq 0.05)$.

\begin{tabular}{|c|c|c|c|c|c|c|c|c|c|c|c|c|c|c|c|}
\hline Treatments & & T1 & $T$ & & T & 3 & & $\Gamma 4$ & & T5 & $T$ & 56 & Exp & $\mathbf{P}$ & C \\
\hline Time (months) & 12 & 24 & 12 & 24 & 12 & 24 & 12 & 24 & 12 & 24 & 12 & 24 & 0 & 12 & 12 \\
\hline $\mathrm{pH}$ & $5.3^{\mathrm{NS}}$ & 6.4 & 5.3 & 6.13 & 5.1 & 6 & 5.4 & 5.9 & 5.3 & 6.1 & 5.3 & 6.4 & 5.4 & 5.8 & 5.9 \\
\hline $\mathrm{Ca}\left(\mathrm{cmol} \mathrm{dm}{ }^{-3}\right)$ & $1.38^{f}$ & $2.22^{\mathrm{bc}}$ & $1.05^{\mathrm{gh}}$ & $1.95^{\mathrm{d}}$ & $0.91^{\mathrm{h}}$ & $2.05^{c d}$ & $1.42^{\mathrm{ef}}$ & $2.01^{\mathrm{cd}}$ & $1.15^{\mathrm{g}}$ & $2.38^{\mathrm{ab}}$ & $1.02^{\mathrm{gh}}$ & $2.45^{\mathrm{a}}$ & $0.54^{i}$ & $2.03^{c d}$ & $1.62^{\mathrm{e}}$ \\
\hline $\mathrm{Mg}\left(\mathrm{cmol} \mathrm{dm^{-3 }}\right)$ & $0.23^{\mathrm{e}}$ & $0.5^{\mathrm{ab}}$ & $0.20^{\mathrm{e}}$ & $0.47^{b}$ & $0.2^{\mathrm{e}}$ & $0.45^{\mathrm{b}}$ & $0.32^{\text {cd }}$ & $0.49^{\mathrm{ab}}$ & $0.27^{\text {de }}$ & $0.49^{\mathrm{ab}}$ & $0.22^{\mathrm{e}}$ & $0.58^{\mathrm{a}}$ & $0.12^{f}$ & $0.35^{c}$ & $0.51^{\mathrm{ab}}$ \\
\hline $\mathrm{K}\left(\mathrm{mg} \mathrm{dm}^{-3}\right)$ & $50^{9}$ & $107^{d}$ & $49^{9}$ & $123^{b c}$ & $48^{\mathrm{s}}$ & $120^{c}$ & $64^{f}$ & $120^{c}$ & $49^{9}$ & $129^{\mathrm{b}}$ & $46^{\mathrm{g}}$ & $148^{\mathrm{a}}$ & $47.0^{\mathrm{g}}$ & $87^{e}$ & $86.3^{e}$ \\
\hline $\mathrm{P}\left(\mathrm{mg} \mathrm{dm}^{-3}\right)$ & $2.5^{\text {efg }}$ & $10.3^{c}$ & $4.3^{\text {de }}$ & $11.0^{c}$ & $2^{f g}$ & $11.0^{c}$ & $2.0^{\mathrm{fg}}$ & $21^{a}$ & $3.0^{\text {efg }}$ & $14.0^{\mathrm{b}}$ & $3.6^{\text {ef }}$ & $15^{\mathrm{b}}$ & $1.0^{\mathrm{g}}$ & $3.66^{\mathrm{ef}}$ & $6.0^{\mathrm{d}}$ \\
\hline $\mathrm{OM}\left(\mathrm{dag} \mathrm{Kg}^{-3}\right)$ & $0.7^{\text {def }}$ & $1.5^{\mathrm{b}}$ & $0.7^{\text {def }}$ & $0.88^{\text {cdef }}$ & $0.66^{f}$ & $1.16^{c}$ & $0.8^{\text {cdef }}$ & $0.99^{c d}$ & $0.79^{\text {cdef }}$ & ef $0.88^{\text {cde }}$ & $0.68^{\text {ef }}$ & $1.0^{\text {cd }}$ & $0.64^{f}$ & $2.28^{\mathrm{a}}$ & $0.90^{\text {cdef }}$ \\
\hline CEC $\left(\mathrm{cmol}_{c} \mathrm{dm}^{-3}\right)$ & $3.5^{\mathrm{e}}$ & $4.4^{\mathrm{bc}}$ & $3.4^{\mathrm{e}}$ & $4.3^{\mathrm{bc}}$ & $3.4^{\mathrm{e}}$ & $4.5^{\mathrm{ab}}$ & $3.6^{\mathrm{de}}$ & $4.5^{\mathrm{ab}}$ & $3.4^{\mathrm{e}}$ & $4.9^{\mathrm{a}}$ & $3.3^{e}$ & $4.9^{\mathrm{a}}$ & $3.4^{e}$ & $3.76^{\mathrm{cd}}$ & 4.19 \\
\hline BS (\%) & $55^{e}$ & $67^{\mathrm{b}}$ & $41^{\mathrm{h}}$ & $63^{c d}$ & $34^{i}$ & $61^{\mathrm{d}}$ & $51^{f}$ & $62^{d}$ & $45^{9}$ & $66^{\mathrm{bc}}$ & $41^{\mathrm{h}}$ & $69^{b}$ & $41^{\mathrm{h}}$ & $78^{a}$ & $56.3^{\mathrm{e}}$ \\
\hline Clay (\%) & - & - & - & - & - & - & - & - & - & - & - & - & 17 & 14 & 16 \\
\hline Sand (\%) & - & - & - & - & - & - & - & - & - & - & - & - & 82 & 84 & 83 \\
\hline Silt (\%) & - & - & - & - & - & - & - & - & - & - & - & - & 1 & 2 & 1 \\
\hline
\end{tabular}

Initial litter nutrient content

The results reported in Tab. 2 show that nitrogen and phosphorus were higher in the leguminous leaves than in the eucalyptus leaves, and as a result, the nutrient content was higher in the mixed than in the

Tab. 2 - Initial nutrients content (\%) of leaves in litter bags. Different letters within columns indicate significant differences among means after Tukey's test $(P<0.05)$.

\begin{tabular}{lccccc}
\hline Litter Type & Nitrogen & Phosphorus & Cellulose & Lignin & Lignin: $N$ \\
\hline Platymenia & 1.322 & 0.040 & 18.88 & 26.44 & 22.43 \\
reticulata & $(0.047)^{\mathrm{a}}$ & $(0.001)^{\mathrm{a}}$ & $(1.11)^{\mathrm{a}}$ & $(0.99)^{\mathrm{a}}$ & $(0.17)^{\mathrm{a}}$ \\
Eucalyptus & 0.705 & 0.031 & 15.16 & 16.35 & 22.43 \\
camaldulensis & $(0.032)^{\mathrm{c}}$ & $(0.006)^{\mathrm{b}}$ & $(1.84)^{\mathrm{b}}$ & $(0.46)^{\mathrm{b}}$ & $(0.21)^{\mathrm{a}}$ \\
P. reticulata + E. & 1.046 & 0.039 & 16.36 & 19.56 & 20.38 \\
camaldulensis & $(0.057)^{\mathrm{b}}$ & $(0.003)^{\mathrm{a}}$ & $(0.66)^{\mathrm{ab}}$ & $(0.39)^{\mathrm{ab}}$ & $(0.87)^{\mathrm{b}}$ \\
\hline
\end{tabular}

Tab. 3 - Decay rate per year $(K)$ of each litter type after 8 months of incubation at the different sites or treatments. Different capital letters within rows and different lowercase letters within columns indicate significant differences among means after Tukey's test $(\mathrm{P}<0.05) .\left({ }^{*}\right)$ : Inoculated with rhizobia and/or AMF.

\begin{tabular}{|c|c|c|c|}
\hline Treatment /sites & $\begin{array}{l}\mathrm{K}\left(\mathrm{year}^{-1}\right) \\
\text { P. reticulata } \\
\text { bags }\end{array}$ & $\begin{array}{c}\mathrm{K}\left(\mathrm{year}^{-1}\right) \\
\begin{array}{c}\text { E. camaldulensis } \\
\text { bags }\end{array}\end{array}$ & $\begin{array}{l}\text { K (year-1) } \\
\text { Mixed litter } \\
\text { bags }\end{array}$ \\
\hline$P$ reticulata & $1.499^{\mathrm{CB}}$ & $2.204^{\mathrm{CA}}$ & $1.685^{\mathrm{dB}}$ \\
\hline$P$ reticulata* & $1.407^{c c}$ & $2.096^{\mathrm{dA}}$ & $1.808^{\mathrm{dB}}$ \\
\hline E. camaldulensis & $2.97^{\mathrm{aB}}$ & $2.935^{\mathrm{bA}}$ & $3.857^{\mathrm{AA}}$ \\
\hline E. camaldulensis * & $2.4^{\mathrm{bB}}$ & $3.45^{\mathrm{aA}}$ & $3.79^{\mathrm{aA}}$ \\
\hline Mixed & $1.5^{c c}$ & $2.09^{\mathrm{dB}}$ & $2.944^{\mathrm{bA}}$ \\
\hline Mixed* & $1.6^{\mathrm{cC}}$ & $2.03^{\mathrm{dB}}$ & $2.435^{c A}$ \\
\hline Carrasco & $0.88^{\mathrm{dc}}$ & $2.22^{\mathrm{cA}}$ & $1.68^{\mathrm{dB}}$ \\
\hline Preserved site & $0.82^{\mathrm{dB}}$ & $0.876^{\mathrm{eAB}}$ & $1.178^{e^{A A}}$ \\
\hline
\end{tabular}

\section{Leaf litter decomposition}

The results reported in Fig. 2 show that, regardless of the incubation site, the leaves of the eucalyptus plants decomposed quickly and exhibited a high decay rate (K Tab. 3). In general, the litter decay rate increased in the order of E. camaldulensis > mixed > Plathymenia reticulata, with the exception of the mixed litter incubated at the mixed site, which showed a higher $\mathrm{K}$ rate than the $E$. camaldulensis leaves under the same conditions (Tab. 3). The ANOVA analysis confirmed that litter type ( $P$. reticulata, E. camaldulensis and mixed litters), site and decomposition time modified the rate of mass loss. However, an interaction was observed between the incubation site (vegetation type) and decomposition time, which significantly affected the loss of mass and nutrients (Tab. 4). For all litter types ( $P$. reticulata, E. camaldulensis and mixed litters), mass loss and phosphorus release were improved when incubated in the Eucalyptus plots (Fig. 2). The decomposition rates at the Plathymenia reticulata and mixed plantation sites were similar. In contrast, all of the litter types showed a slow decomposition rate $(K)$ when incubated at Carrasco and especially at the preserved sites (Fig. 2, Tab. 3), confirming the influence of the site on mass and phosphorus losses (Tab. 4). As for phosphorus release, the preserved site showed a fast decay in the first 4 months, followed by a strong immobilization (Fig. 2). The results

Tab. 4 - ANOVA for mass, nitrogen and phosphorus losses from litter bags, as affected by site (incubation site), species (type of lit ter) and time of field incubation ( 4 and 8 months). $(* * *)$ : $P<0.001 ;(n s)$ : not significant.

\begin{tabular}{|c|c|c|c|c|c|c|c|c|c|}
\hline \multirow{2}{*}{ Sources of variation } & \multicolumn{3}{|c|}{ Mass remaining } & \multicolumn{3}{|c|}{$\mathrm{N}$ remaining } & \multicolumn{3}{|c|}{$P$ remaining } \\
\hline & df & MS & $\mathbf{F}$ & df & MS & $\mathbf{F}$ & df & MS & $\mathbf{F}$ \\
\hline Litter type & 2 & 0.610 & $24.358^{* * *}$ & 2 & 0.019 & $10.264^{* * *}$ & 2 & 0.037 & $16.389^{* * *}$ \\
\hline Site & 7 & 0.548 & $21.890^{* * *}$ & 7 & 0.024 & $12.955^{* * *}$ & 7 & 0.013 & $5.956^{* * *}$ \\
\hline Time & 1 & 14.83 & $592.324^{* * *}$ & 1 & 0.777 & $422.205^{* * *}$ & 1 & 0.610 & $269.167^{* * *}$ \\
\hline Litter type $\times$ Site & 14 & 0.022 & $0.882^{n s}$ & 14 & 0.002 & $1.154^{\mathrm{ns}}$ & 14 & 0.003 & $1.246^{\mathrm{ns}}$ \\
\hline Litter type $\times$ Time & 2 & 0.045 & $1.778^{\mathrm{ns}}$ & 2 & 0.017 & $9.247^{* * *}$ & 2 & 0.013 & $5.678^{* * *}$ \\
\hline Site $\times$ time & 7 & 0.113 & $4.496^{* * *}$ & 7 & 0.017 & $9.062^{* * *}$ & 7 & 0.019 & $8.487^{* * *}$ \\
\hline Error & 341 & 0.025 & - & 341 & 0.002 & - & 341 & 0.002 & - \\
\hline
\end{tabular}


Fig. 2 - Mass loss (left panels) and phosphorus release (right panels) of Plathymenia reticulata $(\mathrm{A})$, Eucalyptus camaldulensis (B) and mixed (C) leaves in litterbags, 4 and 8 months after incubation at different sites. $(*)$ : inoculated with rhizobia and or arbuscular mycorrhiza fungi (AMF).
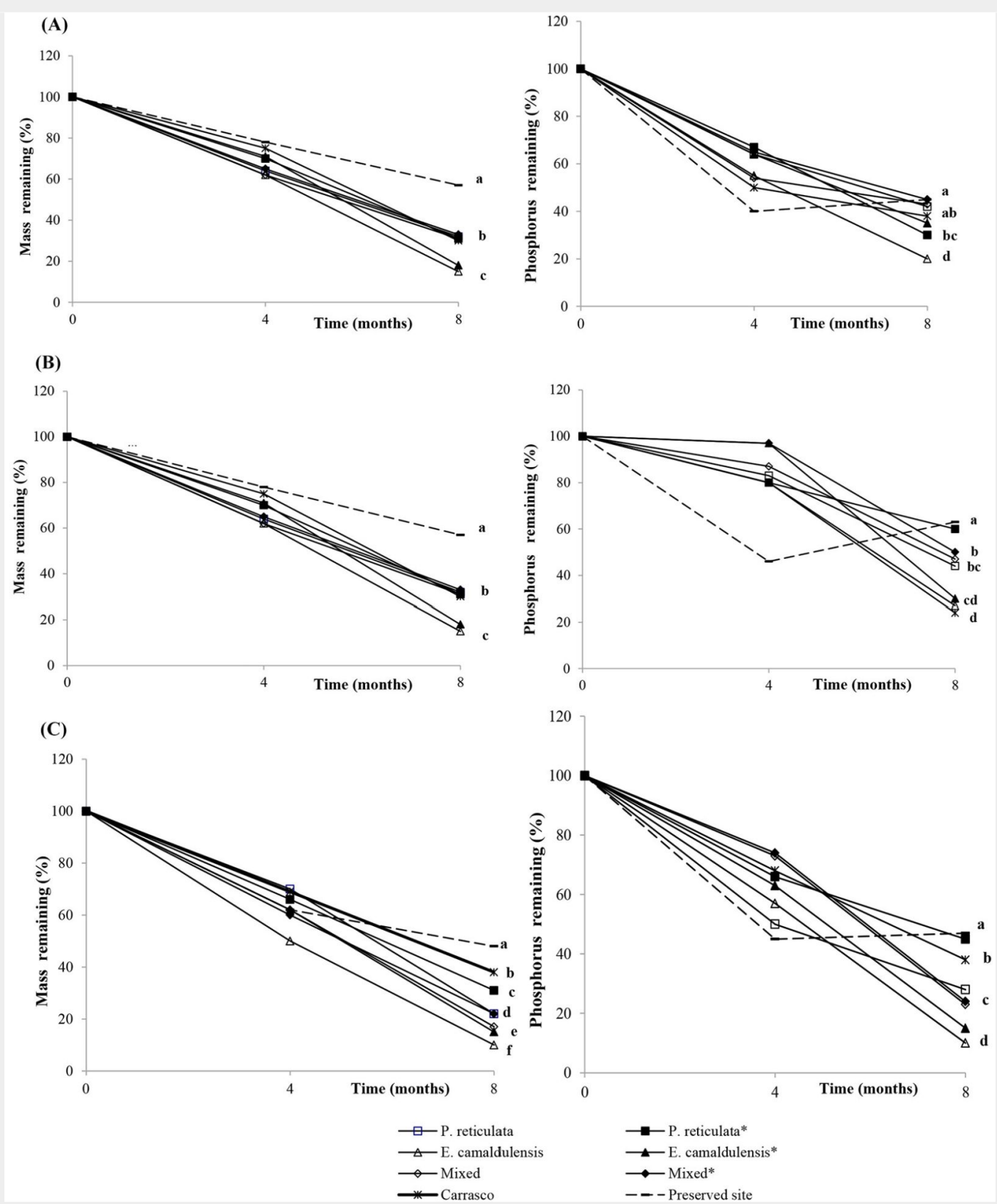

presented in Fig. 3 revealed that the preserved site had a significantly larger microbial population $\left(C_{\text {mic }}\right)$ than all of the other sites.

Phosphate-solubilizing microorganisms (PSM) and acid phosphatase activity

The PSM population significantly improved in the litter-bag soils from the mixed plantation and preserved sites compared with that at the Carrasco site (Fig. 4A). In addition, acid phosphatase activity was high not only in the litter-bag soils from the preserved site and mixed plots but also in the Eucalyptus plots where the plants were not inoculated with AMF (Fig. 4B).

The dominant phosphate-solubilizing fungi (PSF) isolates from each site were identified based on the DNA sequence at the ITS regions (Fig. 5A). In contrast to the high dominance of Aspergillus sp. found in the preserved, mixed and $E$. camaldulensis plots, smaller populations and lower diver-

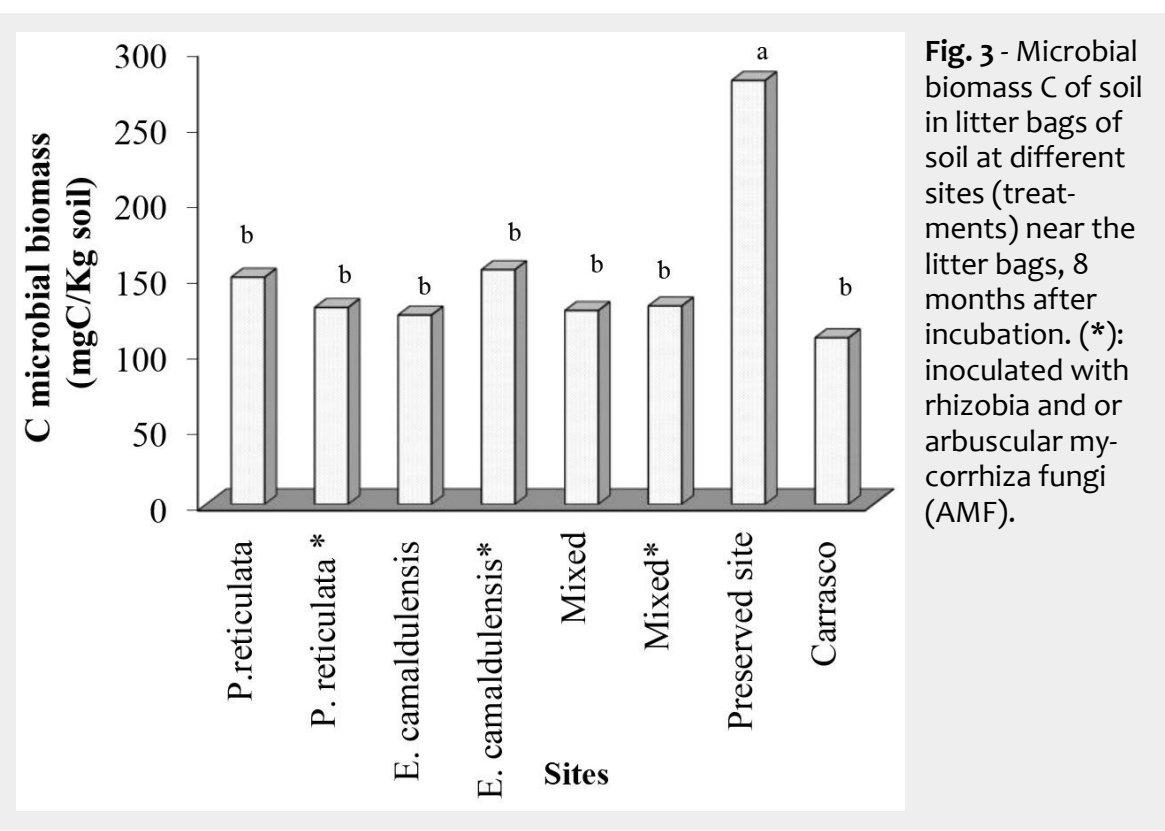



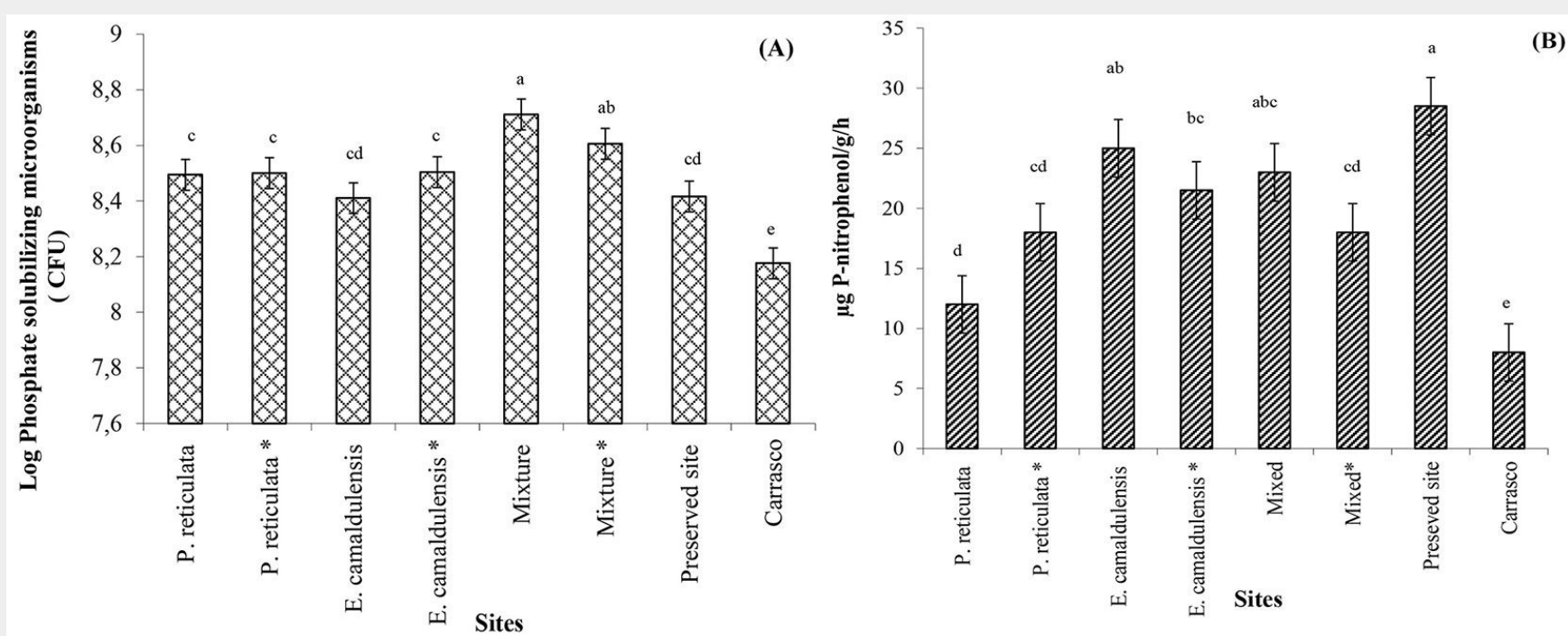

Fig. 4 - Phosphate-solubilizing microorganism (A) and soil phosphatase activity assayed by the p-nitrophenyl phosphate method ( $\mu$ g $\mathrm{p}$-nitrophenol/g/h) (B) in the soil near the mixed litter bags at the different sites after 8 months of incubation.

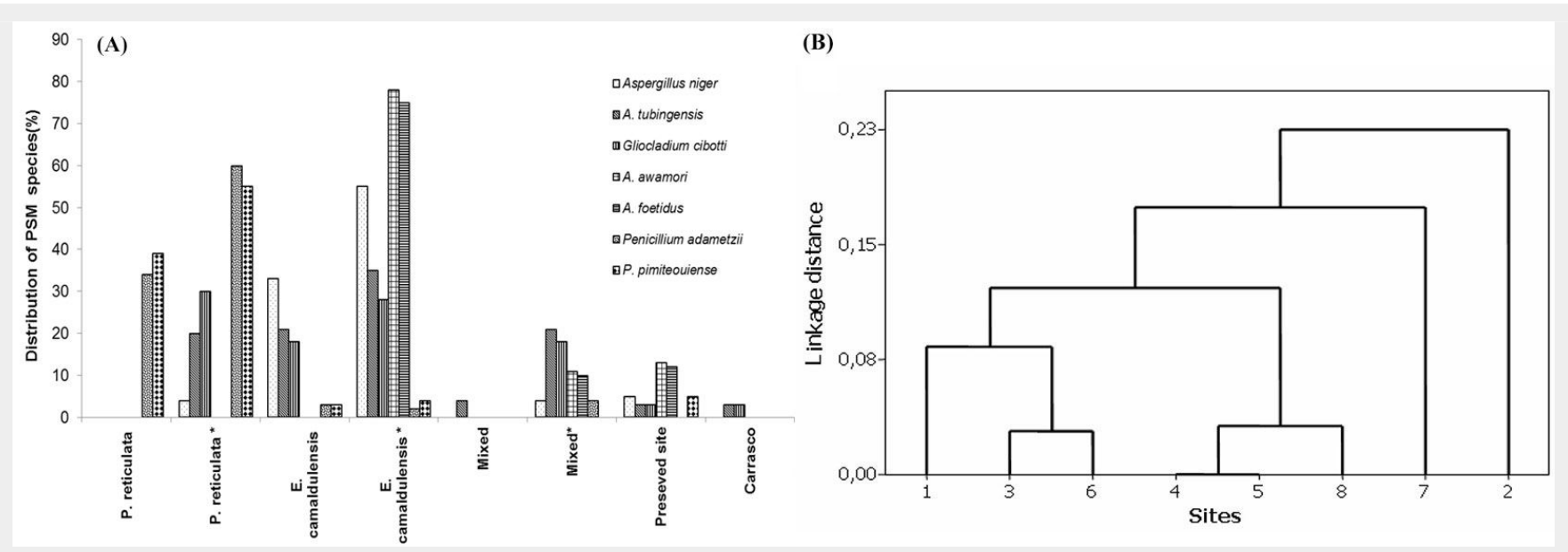

Fig. 5 - (A) Distribution of phosphate-solubilizing fungi (PSF) species identified based on rDNA sequences via Gen Bank Nucleotide Database using the BLAST program. (B) UPGMA dendrogram of phosphate-solubilizing fungi (PSF) species present at each studied site based on the Sorensen's similarity Index. (1): P. reticulata; (2): P. reticulata*; (3): E. camaldulensis; (4): E. camaldulensis*; (5): Mixed; (6): Mixed*; (7): Carrasco; (8): preserved site; (*): inoculated with rhizobia and or arbuscular mycorrhiza fungi (AMF).

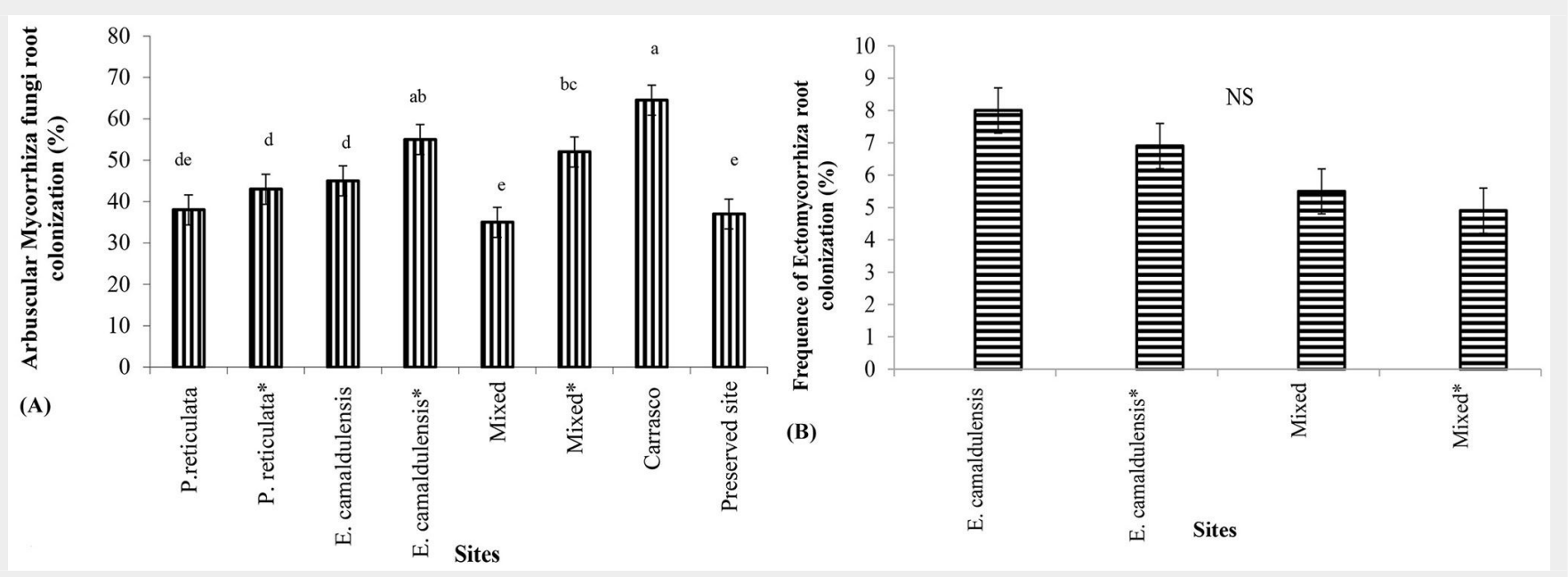

Fig. 6 - Arbuscular mycorrhizal fungi (AMF) root colonization (A) and Ectomycorrhizal root frequence (B) found into the litterbags buried in the rhizosfere of plants at the different studied sites after 8 months of incubation. 


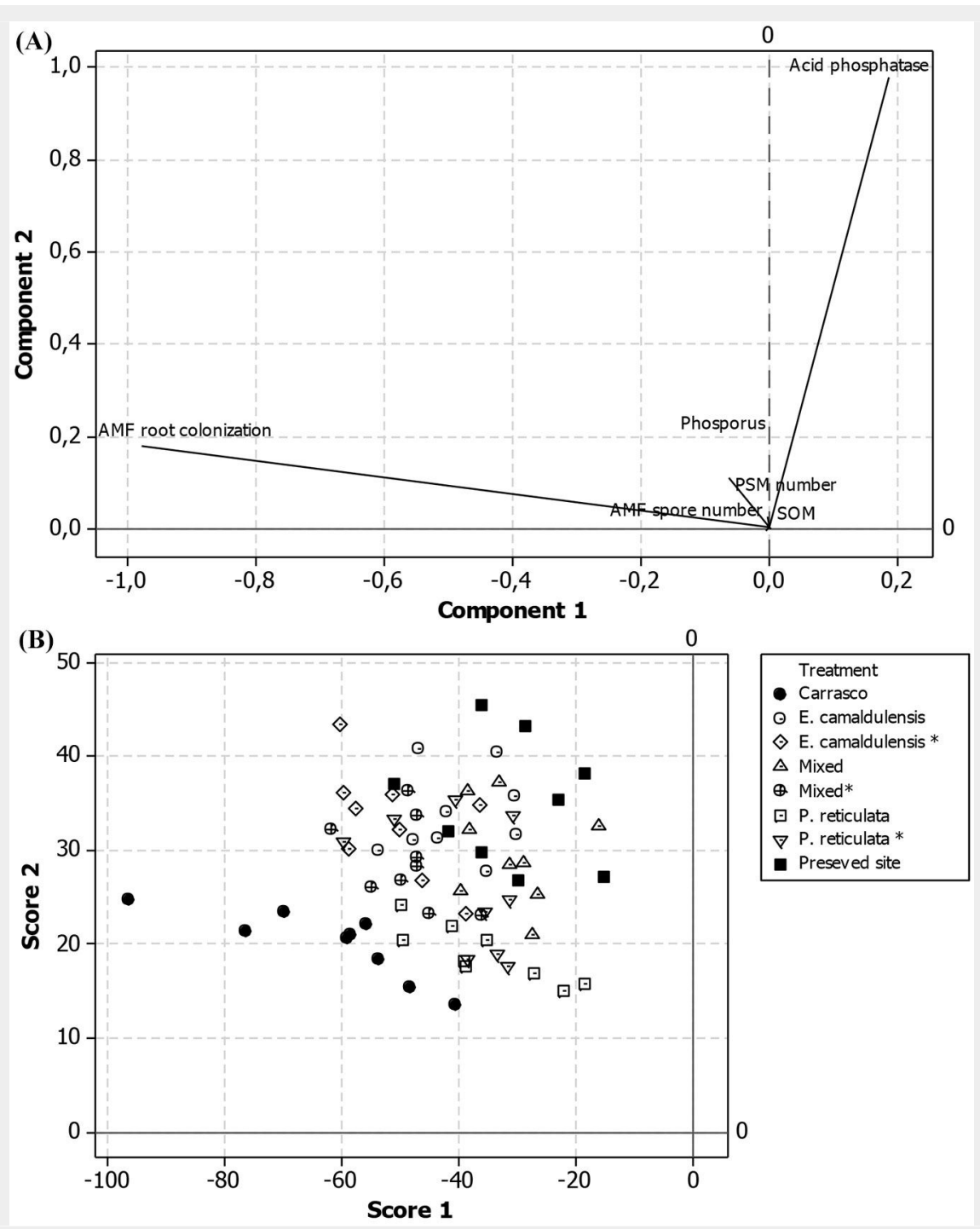

Fig. 7 - (A) Results of the principal component analysis (PCA) based on soil properties (SOM, Phosphorus concentration, phosphatase activity, microbial population of PSM, AMF spore number and AMF root colonization level) for samples from the eight studied sites. The first two axes explained $93 \%$ of the total variation in the dataset. (B) Scatterplot of the samples (stratified by studied site/treatment) based on their scores on the first two PC axes.

sity of these species were recorded at the Carrasco site (Fig. 5B). However, Penicillium was the dominant genus in the $P$. reticulata plot (Fig. 5A). Such differences in PSF distribution resulted from similarities between the preserved site and most of the experimental sites based on the Sorensen's similarity index (Fig. 5B). However, the Carrasco PSF species, particularly those found in the $P$. reticulata sites, were clearly separate, as shown in Fig. 5B.

\section{Mycorrhizal root colonization in the litter bags}

AMF was found to consistently colonize the roots that penetrated the litter bags, especially those under the Carrasco vegetation, E. camaldulensis and mixed sites inoculated with AMF spores (Fig. 6A). Natural ectomycorrhizal root colonization was also noted at sites where eucalyptus plants were cultivated (Fig. 6B), but no significant differences were recorded among different sites.

\section{Principal component analysis}

PCA (Fig. 7A) was carried out using the biological and chemical characteristics of the soil samples collected from the litter bags, which were related to phosphorus metabolism (SOM, soil phosphorus concentration, phosphatase activity, PSM, AMF population spore number - data previously described by Pagano et al. (2011) as well as AMF root colonization). Overall, the first two components accounted for 93.2\% of the total variation in the dataset (PC1: $72.6 \%, P C 2$ : 20.6\%), while the other components do not appear to be relevant to the results. The AMF root colonization variable had the largest loading on the first PC axis (Fig. 7A), while the acid phosphatase activity showed the largest loading on the second axis.
Fig. 7B displays the scatterplot for all the treatments/sites based on their scores on the first two PC axes. It is worth to notice that samples from the Carrasco site are clearly distinguished from samples from the preserved site, while those from experimental sites appeared to be intermediate between them. However, the samples from the eucalyptus and mixed plantation plots appeared to be more similar to those from the preserved site than the Carrasco site.

\section{Discussion}

Phosphorus was a limiting factor to plant growth at the experimental site, but SOM and phosphorus content improved after 24 months from transplantation as compared with those 12 months after transplantation. Therefore, such improvement could not be attributed to the initial fertilization. Litter fall nutrient concentration is related to the intensity of re-translocation processes (Salehi et al. 2013). As the lignin: $\mathrm{N}$ ratio and the lignin chemical composition regulate the decomposition rate, it might be predicted that the rate of decomposition of the leguminous leaves would be slower than the eucalyptus leaves, as it was observed.

As nitrogen and phosphorus were higher in the leguminous leaves than the Eucalyptus leaves, higher phosphorus content was expected in these soils. However, phosphorus was higher in soils samples from the Eucalyptus and mixed plots, particularly in the inoculated plot (treatment T6), compared with the P. reticulata plots. Phosphorus at the Carrasco plot was also higher than that at the preserved site. Plant species alter soil nutrient input through litter quality and the decomposition rate of the microbial community (Miki et al. 2010). Thus, litter quality and the rhizosphere control decomposition processes by selecting the decomposing microorganisms (Hobbie 1992, Turner et al. 2007).

It is known that E. camaldulensis litter has a faster decomposition rate (Mahmood et al. 2009). In this study, the Eucalyptus litter at the experimental site decomposed faster than the mixture, whereas the $P$. reticulata litter alone showed the slowest decay, which is likely due to the low lignin content of the former and the high lignin content of the latter. Therefore, nutrients were released in the following order: Eucalyptus litter $>$ mixture $>P$. reticulata. However, all litter types showed a slow decay rate when incubated at the Carrasco and preserved sites, suggesting a significant effect of vegetation type and density over mass and $P$ losses. These results are an effect of soil nutrient availability under the vegetation at the Carrasco and preserved sites.

Phosphorus concentrations in plant litter tend to be low compared with decomposer requirements when the microbial population is too large, as it is the case at the preserved site, thus decomposers will initially immobilize the nutrients (Berg 2000). In fact, the soil microbial population was sig- 
nificantly high only at the preserved site, as shown by the $C_{\text {mic }}$ assay, which could be an effect mediated by such dense and diverse plant community. Consequently, phosphorus was not released at the preserved site during the 8 months of incubation. In contrast, nutrient demand was high in the Carrasco soils, regardless of the high number of pioneer species, but the decomposition rate of the lignified litter was low. This result may be explained by the poor microbial community, though the latter decomposed the non-lignified litter (Eucalyptus). The above results suggest the existence of differences in the microbial populations between the preserved and Carrasco sites, but do not explain the high phosphorus content in the Carrasco soil.

Nutrients were released and were available to plants that showed a high nutrient demand, such as at the Carrasco and the experimental sites composed of pioneer species and young plants, respectively. Therefore, nutrient immobilization did not occur at these sites.

Phosphorus uptake by plants is assumed to be a function of the phosphorus concentration in the soil solution, which is derived from litter decomposition in the natural environment. Coexisting plants can acquire organic phosphorus through a variety of mechanisms (Turner et al. 2007). Inorganic and organic phosphorus become available by either plant or microorganism activities, particularly those linked to the phosphorus-cycle, such as AMF and PSM (Koide \& Kabir 2000). While the inorganic phosphorus is released through the production of organic anions, the organic phosphorus is hydrolyzed by phosphatase enzymes (Richardson et al. 2009).

Since the roots reaching the litter bags in the Carrasco vegetation were strongly colonized by AMF (whose spores increase significantly at this site - Pagano et al. 2011), and the elevated soil phosphorus content was not correlated with the microbial biomass, such an increase in soil phosphorus was likely due to AMF activity. Indeed, the AMF root colonization at the experimental site was particularly high in the inoculated plots. These results suggest that AMF benefited by the decomposed products (Talbot et al. 2008). However, AMF are known to excrete alkaline phosphatases (Gianinazzi et al. 1979), which could partially explain the low acid phosphatase activity found under the Carrasco vegetation.

AMF root colonization in the litter bags was also high in the E. camaldulensis plots but low in those at the preserved site, which confirmed the role of microorganisms in the release of organic phosphorus. Nutrient uptake via symbiotic associations and soil microbial activities is a likely strategy of pioneer plants (Vinton \& Goergen 2006). Such microbial associations are particularly relevant to Eucalyptus plants that used simultaneously different sources of organic and inorganic phosphorus, as suggested by the fact that the roots in the lit- ter bags were colonized by both endo(AMF) and ectomycorrhizal fungi.

In addition, a high number of PSM and a significant acid phosphatase activity were observed in the Eucalyptus plots. When Eucalyptus was mixed with native species, both AMF and PSM were moderately stimulated. However, not only were the PSM dominant in the rhizosphere of the noninoculated AMF plants, but the PSM population was also inhibited in the Carrasco soil where AMF was dominant. These results suggest that AMF and PSM show the same functional behavior but worked independently from each other, although synergic actions have been reported to occur in others case (Souchie et al. 2006). Furthermore, both ectomycorrhizal fungi and PSM produce acid phosphatases (Conn \& Dighton 2000), which explains the increase of these enzymes in single and mixed Eucalyptus plantations, as well as the accelerated mass and nutrient losses in the litter bags.

A high number of PSF and significant acid phosphatase activity were found in the soil closest to the litter bags at the preserved site. It may be hypothesized that both Eucalyptus and other species from the preserved site shared the same strategy for phosphorus acquisition, by favoring the PSF diversity and the enzyme activity in the litter bags or through the excretion of phosphatase by the plants themselves (Dinkelaker \& Marschner 1992).

The great diversity of Aspergillus sp. at the preserved site and at most intercropped experimental plots was sufficient to clearly separate this group from the disturbed Carrasco site and the $P$. reticulata monoculture site. It is likely that such distribution reflected the functional diversity expressed by the phosphatase activity, which was much lower at the Carrasco site than at the preserved site.

Phosphatase enzymes are soil-quality indicators because they respond to site-management and land use changes (Hinsinger et al. 2011). In fact, specific soil microbial populations involved in the decomposition of organic matter are associated with the vegetation type. In this study, AMF were favored at the Carrasco vegetation sites, the Eucalyptus sites were characterized by AMF, ectomycorrhizal fungi and PSM, while the AMF and PSM groups were more abundant at the intercropped plantation sites. In contrast, the PSM activity was favored at the preserved site. According to previous reports (Mahmood et al. 2009), E. camaldulensis ensured the supply of phosphorous to the agroforestry system by favoring AMF and PSF activities, as determined by the AMF root colonization and the phosphatase activity, respectively. Finally, these microbial populations may be indicators of soil quality useful in assessing the effectiveness of land restoration in semiarid environments.

\section{Conclusions}

The main results of this study may be summarized as follows:

- the vegetation type can affect the litter decomposition rate through the associated microbial communities;

- the Carrasco vegetation (disturbed site) is mainly characterized by arbuscular mycorrhizal fungi (AMF), the preserved site by the PSM population, the Eucalyptus stands by AMF, ectomycorrhizal fungi (EM) and phosphate-solubilizing microorganisms (PSM), while the intercropping system by the AMF and PSM groups.

- the $P$ supply to the agroforestry system may be improved by Eucalyptus camaldulensis in single or intercropped plantations, through the litter decomposition operated by $\mathrm{P}$-cycle related microorganisms.

- AMF root colonization and phosphatase activity might be considered useful indicators of land restoration in agroforestry systems. Based on them, the experimental site appears to be closer to the preserved site.

\section{Acknowledgements}

This research was supported by the Brazilian Ministry of Environment through the National Found of Environment (FNMMA). The authors are grateful to CAPES (Coordenação de Aperfeiçoamento de Pessoal de Nível Superior), CNPq (Conselho Nacional de Pesquisa) and FAPEMIG (Fundação de Amparo a Pesquisa de Minas Gerais) for scholarships.

\section{References}

Aggarwal A, Kadian N, Tanwar A, Yadav A, Gupta KK (2011). Role of arbuscular mycorrhizal fungi (AMF) in global sustainable development. Journal of Applied and Natural Science 3: 340-351. [online] URL: http://ansfoundation.org/Upload edPdf/32/340-351.pdf

Appiah MR, Sackey ST, Ofori-Frimpong K, Afrifa AA (1997). The consequences of cocoa production on soil fertility in Ghana: a review. Ghana Journal of Agricultural Science 30: 183-190. doi: 10.4314/gjas.v30i2

Arruda DM, Ferreira-Júnior WG, Brasil RD, Schaefer CER (2013). Phytogeographical patterns of dry forests sensu strictu in northern Minas Gerais State, Brazil. Anais Academia Brasileira de Ciências 85: 623-634. - doi: 10.1590/Sooo137652013000200011

Berg B (2000). Litter decomposition and organic matter turnover in northern forest soils. Forest Ecology and Management 133: 13-22. - doi: 10.1016/S03781127(99)00294-7

Conn C, Dighton J (2000). Litter quality influences on decomposition, ectomycorrhizal community structure and mycorrhizal root surface acid phosphatase activity. Soil Biology and Biochemistry 32: 489-496. - doi: 10.1016/S0038-0717 (99)00178-9

Del Rey DI (1991). Vegetação e manejo de solos projeto Jaiba [Vegetation and soil management - Jaiba Project]. Relatório $n^{\circ} 5$, Distrito de Irrigação do Jaiba, Belo Horizonte, Brazil, pp. 2560. [in Portuguese]

Dinkelaker B, Marschner H (1992). In vivo demonstration of acid phosphatase activity in the 
rhizosphere of soil-grown plants. Plant and Soil 144: 199-205. - doi: 10.1007/BFoo012876

EMBRAPA (1997). Manual de métodos de análises do solo [Manual of soil analysis methods] ( $2^{\text {nd }}$ edn). Centro Nacional de Pesquisas de Solos, Empresa Brasileira de Pesquisas Agropecuária - Embrapa solos, Rio de Janeiro, Brazil, pp. 13-196. [in Portuguese]

Fuxu W, Ping C (2004). Soil enzyme activities under agroforestry systems in northern Jiangsu province. Forestry Studies in China 6: 21-26. doi: 10.1007/s11632-004-0015-3

Gianinazzi S, Gianinazzi-Pearson V, Dexheimer J (1979). Enzymatic studies on the metabolism of vesicular-arbuscular mycorrhiza. III. Ultrastructural localization of acid and alkaline phosphatase in onion roots infected by Glomus mosseae (Nicol. \& Gerd). New Phytologist 82: 127-132. doi: 10.1111/j.1469-8137.1979.tb07566.x

Goering HK, Van Soest PJ (1970). Forage fiber analyses: apparatus, reagents, procedures, and some applications. Agricultural Handbook No. 379, USDA, Washington, DC, USA, pp. 20.

Herman DJ, Firestone MK, Nuccio E, Hodge A (2012). Interactions between an arbuscular mycorrhizal fungus and soil microbial community mediating litter decomposition. FEMS Microbiology and Ecology 80: 236-247. - doi: 10.1111/j. 1574-6941.2011.01292.x

Hinsinger $P$, Betencourt $E$, Bernard L, Brauman A, Plassard C, Shen J, Tang X, Zhang F (2011). P for two, sharing a scarce resource: soil phosphorus acquisition in the rhizosphere of intercropped species. Plant Physiology 156: 10781086. - doi: 10.1104/pp.111.175331

Hobbie SE (1992). Effects of plant species on nutrient cycling. Tree 7: 336-339. - doi: 10.1016/01 69-5347(92)90126

Jalonen R, Timonen S, Sierra J, Nygren P (2013). Arbuscular mycorrhizal symbioses in a cut-andcarry forage production system of legume tree Gliricidia sepium and fodder grass Dichanthium aristatum. Agroforestry Systems 87: 319-330. doi: 10.1007/s10457-012-9553-1

Koide RT, Kabir Z (2000). Extraradical hyphae of the mycorrhizal fungus Glomus intraradices can hydrolyse organic phosphate. New Phytologist 148: 511-517. - doi: 10.1046/j.1469-8137.2000.007 76.x

Lapeyrie F, Ranger J, Vairelles D (1990). Phosphate solubilizing activity of ectomycorrhizal fungi in vitro. Canadian Journal of Botany 69: 342-346. - doi: 10.1139/b91-046

Lee $\mathrm{KH}$, Jose S (2003). Soil respiration and microbial biomass in a pecan-cotton alley cropping system in southern USA. Agroforestry Systems 58: 45-54. - doi: 10.1023/A:1025404019211

Lee SB, Taylor JW (1990). Isolation of DNA from fungal mycelia and single spores. In: "PCR Protocols. A Guide to Methods and Applications" (Innis MA, Gelfand DH, Sninsky JJ, White TJ eds). Academic Press, San Diego, USA, pp. 282287.

Mahmood H, Limon SH, Rahman MS, Azad AK, Islam MS, Khairuzzaman M (2009). Nutrients $(\mathrm{N}, \mathrm{P}$ and $\mathrm{K}$ ) dynamics associated with the leaf litter of two agroforestry tree species of Bangladesh. iForest 2: 183-186. - doi: 10.3832/iforo5 10-002

Matias SR, Pagano MC, Muzzi FC, Oliveira CA, Carneiro AA, Horta NS, Scotti MR (2009). Effect of rhizobia, mycorrhizal fungi and phosphatesolubilizing microorganisms in the rhizosphere of native plants used to recover an iron ore area in Brazil. European Journal of Soil Biology 45: 259-266. - doi: 10.1016/j.ejsobi.2009.02.003

McGonigle TP, Millers MH, Evans DG, Fairchild GL, Swan JA (1990). A new method which gives an objective measure of colonization of roots by vesicular-arbuscular mycorrhizal fungi. New Phytologist 115: 495-501. - doi: 10.1111/j.1469-813 7.1990.tboo476.x

Miki T, Ushio M, Fukui S, Kondoh M (2010). Functional diversity of microbial decomposers facilitates plant coexistence in a plant-microbe-soil feedback model. Proceedings of the National Academy of Sciences USA 107: 14251-14256. doi: 10.1073/pnas.0914281107

Nair PKR, Latt CR (1997). Directions in tropical agroforestry research. Agroforestry System 38: 1-249. - doi: 10.1023/A:1005943729654

Nguyen C, Yan W, Le Tacon F, Lapeyrie F (1992). Genetic variability of phosphate solubilizing activity by monocaryotic and dicaryotic mycelia of the ectomycorrhizal fungus Laccaria bicolor (Maire) P. D. Orton. Plant and Soil 143: 193-199. doi: 10.1007/BFoo007873

Oliveira SA (1986). Método simplificado para determinação colorimétrica de nitrogênio em plantas. [Simplified method for colorimetric determination of nitrogen in plants]. Ciência y Cultura 38: 178-180. [in Portuguese]

Olson JS (1963). Energy storage and the balance of producers and decomposers in ecological systems. Ecology 44: 322-331. - doi: 10.2307/193 2179

Pagano MC, Cabello MN, Bellote AF, Sã NMH, Scotti MR (2008). Intercropping system of tropical leguminous species and Eucalyptus camaldulensis, inoculated with rhizobia and/or mycorrhizal fungi in semiarid Brazil. Agroforestry Systems 74: 231-242. - doi: 10.1007/s10457-0089177-7

Pagano MC, Utida MK, Gomes EA, Marriel IE, Cabello MN, Scotti MR (2011). Plant-type dependent changes in arbuscular mycorrhizal communities as soil quality indicator in semiarid Brazil. Ecological Indicators 11: 643-650. doi: 10.1016/j.ecolind.2010.09.001

Partey ST, Quashie-Sam SJ, Thevathasan NV, Gordon AM (2011). Decomposition and nutrient release patterns of the leaf biomass of the wild sunflower (Tithonia diversifolia): a comparative study with four leguminous agroforestry species. Agroforestry Systems 81: 123-134. - doi: 10.1007/s10457-010-9360-5

Pikovskaya RI (1948). Mobilization of phosphorus in soil in connection with vital activities by some microbial species. Mikrobiologia 17: 362370.

Richardson AE, Barea JM, McNeill AM, PrigentCombaret C (2009). Acquisition of phosphorus and nitrogen in the rhizosphere and plant growth promotion by microorganisms. Plant and Soil 321: 305-339. - doi: 10.1007/s11104-0099895-2

Rizzini CT (1997). Tratado de fitogeografia do Brasil: aspectos ecológicos, sociológicos e florísticos [Treaty of plant geography of Brazil: ecological, sociological and floristic aspects]. Ambito Cultural Edições Ltda, Rio de Janeiro, Brazil, pp. 747 [in Portuguese]
Salehi A, Ghorbanzadeh N, Salehi M (2013). Soil nutrient status, nutrient return and retranslocation in poplar species and clones in northern Iran. iForest 6: 336-341. - doi: 10.3832/iforo976006

Sampaio IBM (2002). Estatística aplicada à experimentação animal [Statistics applied to animal experimentation]. Fundação de Estudo e Pesquisa em Medicina Veterinária, Belo Horizonte, Brazil, pp. 221. [in Portuguese]

Sarruge JR, Haag HP (1974). Análises químicas em plantas [Chemical analysis in plants]. Escola Superior de Agricultura Luiz de Queiroz (ESALQ). Piracicaba, São Paulo, Brazil, pp. 56 . [in Portuguese]

Singh JS, Raghubanshi AS, Singh RS, Srivastava SC (1989). Microbial biomass acts as a source of plant nutrients in dry tropical forest and Savanna. Nature 338: 499-500. - doi: 10.1038/33849 gao

Somasegaran P, Hoben HJ (1985). Methods in legume - Rhizobium technology. NifTAL, MIRCEN University of Hawaii Press, Maui, Hawaii, USA, pp. 361.

Souchie EL, Azcón R, Barea JM, Saggin-Júnior OJ, Silva EMR (2006). Phosphate solubilization and synergism between P-solubilizing and arbuscular mycorrhizal fungi. Pesquisa Agropecuária Brasileira 41: 1405-1411. - doi: 10.1590/ S0100-204X2006000900009

Tabatabai MA (1982). Soil enzymes. In: “Methods of Soil Analysis - Part 2" (Page AL, Miller $\mathrm{RH}$, Keeney DR eds). American Society Agronomy, Madison, WI, USA, pp. 943-947.

Talbot JMS, Allison D, Treseder KK (2008). Decomposers in disguise: mycorrhizal fungi as regulators of soil $C$ dynamics in ecosystems under global change. Functional Ecology 22: 955-963. - doi: 10.1111/j.1365-2435.2008.01402.x Turner BL, Condron LM, Richardson SJ, Peltzer DA, Allison VJ (2007). Soil organic phosphorus transformations during pedogenesis. Ecosystems 10: 1166-1181. - doi: 10.1007/slo021-0079086-z

Van der Heijden MGA, Bardgett RD, Van Straale NM (2008). The unseen majority: soil microbes as drivers of plant diversity and productivity in terrestrial ecosystems. Ecology Letters 11: 296310. - doi: 10.1111/j.1461-0248.2007.01139.x

Vance ED, Brooks PC, Jenkison DS (1987). An extraction method for measuring soil microbial biomass C. Soil Biology and Biochemistry 19: 703-707. - doi: 10.1016/0038-0717(87)90052-6

Vinton MA, Goergen EM (2006). Plant-soil feedbacks contribute to the persistence of Bromus inermis in tallgrass prairie. Ecosystems 9: 967976. - doi: 10.1007/s10021-005-0107-5

Wesemael BV (1993). Litter decomposition and nutrient distribution in humus profiles in some Mediterranean forests in southern Tuscany. Forest Ecology and Management 57: 99-114. - doi: 10.1016/0378-1127(93)90165-J

White TJ, Bruns T, Lee S, Taylor JW (1990). Amplification and direct sequencing of fungal ribosomal RNA genes for phylogenetics. In: "PCR Protocols: A Guide to Methods and Applications" (Innis MA, Gelfand DH, Sninsky JJ, White TJ eds). Academic Press, San Diego, CA, USA, pp. 315-322. 